\title{
Expression of Steroidogenesis-related Genes in Rat Adipose Tissues
}

\author{
Hye Rim Byeon and ${ }^{\dagger}$ Sung-Ho Lee \\ Dept. of Life Science, Sangmyung University, Seoul 03016, Korea
}

\begin{abstract}
Adipose tissue is one of the major endocrine gland. More recently, local production of steroids in adipocytes differentiated from mouse 3T3-L1 cell-line was reported. We hypothesized that rat adipocytes have steroidogenic machinery and the expression patterns of the components might be differentially regulated, depending on the distribution and sex. To verify this hypothesis, we collected the adipose tissues depot- and sex-specifically at postnatal day (PND) 30, and performed quantitative RT-PCRs. In overall aspects, the abundances of the transcripts were lower in the brown adipose of both sexes. $3 \beta$-HSD transcript levels in female abdominal and reproductive adipose, CYP17 transcript levels in female reproductive adipose, 17 $\beta$-HSD transcript levels in female abdominal and reproductive adipose, and CYP19 transcript levels in female abdominal adipose were significantly lower than those of male counterparts. Similar to steroidogenic factors, the abundance of the ER- $\alpha$ transcripts were generally lower in the brown adipose of both sexes. ER- $\beta$ transcripts were more abundant in male white adipose depots than their female counterparts. The levels of LHR transcripts in female reproductive adipose were significantly higher than those of male counterpart. In conclusion, our study demonstrated that the expressions of steroidogenesis-related genes were depot- and sex-specifically occurred in the immature male and female rat adipose tissues. Our study suggested that the adipose tissues are not only targets but de novo synthesizing sites of sex steroid(s), though the synthesizing activities could be much less than in gonads. Further researches in this field will be helpful for understanding the adipose physiology and for medical application such as sex-specific steroid supplement therapies for older populations.
\end{abstract}

Key words : Rat, Brown adipose tissue, White adipose tissue, Steroidogenic factors

\section{INTRODUCTION}

According to the World Health Organization (WHO), obesity is a complex condition which affects virtually all age and socioeconomic groups and threatens to overwhelm both developed and developing countries. Since obesity is a medical circumstance in which excess body fat has accumulated to the extent, there has been considerable accumulation of research information about the adipose biology (Coelho et al., 2013). Several lines of evidence indicate that gonadal sex steroids are sex-specifically involved in the accumulation and distribution of adipose tissues. For example, distribution of fat is different between males and females; men have a more central accumulation of fat, whereas women have a more gluteal/femoral accumulation (Bjorntorp, 1996).

Meanwhile, it has become evident that adipose tissue is one of the major endocrine gland (Coelho et al., 2013). For

\footnotetext{
Manuscript received July 04, 2016, Received in revised form July 28, 2016, Accepted September 13, 2016

${ }^{\dagger}$ Corresponding Author: Sung-Ho Lee, Dept. of Life Science, Sangmyung University, Seoul 03016, Korea. Tel. : +82-2-2287-5139, Fax : +82-2-22870070, E-mail : shlee@smu.ac.kr

This is an Open Access article distributed under the terms of the Creative Commons Attribution Non-Commercial License (http:// creativecommons.org/licenses/by-nc/3.0) which permits unrestricted non-commercial use, distribution, and reproduction in any medium, provided the original work is properly cited.
} 
a long time, adipocyte, also known as a fat cell, had been considered to be an inert cell that just stores fat. The importance of adipose tissue as an endocrine organ was fully appreciated in 1995 with the discovery of leptin, the protein product of the $O b$ gene (Pelleymounter et al., 1995). By the way, the endocrine potency such as aromatization of testosterone in adipose tissues also has been well noticed from studies using castrated animal models (Drago et al., 1982; Zhao et al., 2005). Analyses of human adipose tissue also revealed that several genes involved in steroidogenesis were expressed in adipose tissue (MacKenzie et al., 2008b). More recently, local production of steroids in adipocytes differentiated from mouse 3T3-L1 cell-line was reported ( $\mathrm{Li}$ et al., 2014).

In the present study, we hypothesized that rat adipocytes have steroidogenic machinery and expression patterns of the components might be depot- and sex-specific. To verify this hypothesis, we collected the brown adipose tissue (BAT) and white adipose tissue (WAT), and subdivided the WAT into abdominal and reproductive fats from immature male and female rats. After the tissue collections, we performed semi-quantitative RT-PCRs for steroidogenic factors.

\section{MATERIALS \& METHODS}

\section{Animals}

Postweaned Sprague-Dawley rats (PND 22) were obtained from Han-Lim Animal (Gyunggi-do, Korea) and reared in Sangmyung University animal facility under conditions of 12-h light/dark cycle (lights on at 07:00 h) and constant temperature of $22 \pm 1^{\circ} \mathrm{C}$. Rats had free access to normal chow and tap water (ad libitum). All procedures used were approved by the Animal Care and Use Committee at Sangmyung University in accordance with guidelines established by the Korea Food and Drug Administration (KFDA).

\section{Experimental design}

After allowing 8 days acclimation, male and female animals were sacrificed and the adipose tissues were collected. The tissues were subdivided into abdominal (visceral fat over the intestines) and reproductive fats (also known as gonadal fats; epididymal and ovarian fat pad from male and female, respectively). Tissue samples were used to prepare the RNAs, and some part were used to confirm the morphological integrity of the collected tissues.

\section{Histology}

Tissue specimens were fixed $4 \%$ paraformaldehyde at $4^{\circ} \mathrm{C}$ for $24 \mathrm{~h}$. Fixed tissues were serially dehydrated in graded ethanol and xylene. Specimens were embedded in paraffin block. The tissues blocks were cut at $6 \mu \mathrm{m}$ using microtome (HM350S, MICROM, Germany). Sections were stained with hematoxylin-eosin stain and examined under light microscope (BX51, Olympus, Japan).

\section{Total RNA extraction and reverse transcriptase} PCR analyses

Total RNAs were isolated from tissue samples using the single-step, acid guanidinum thiocyanate-phenol-chloroform extraction method. Total RNAs were used in RT-PCR reactions carried out with Maxime ${ }^{\mathrm{TM}}$ RT PreMix (InTron, Korea) and Accupower PCR Premix (GeneAll, Korea) according to the manufacturer's instructions. Sequences of the primers and the specific PCR conditions used in this study were successfully worked in the previous study (Yoo \& Lee, 2016), and were listed in Tables 1 and 2, respectively. The reaction products were analyzed by gel electrophoresis in $1.5 \%$ agarose gel $(75 \mathrm{~V}, 65 \mathrm{~min})$ and visualized by ethidium bromide staining. The band intensities were measured using the image analysis system (ImagerIII-1D main soft ware, Bioneer, Korea). Glyceraldehydes-3-phosphate dehydrogenase (GAPDH) was used as reference gene for normalization of quantitative RT-PCRs in the present study. 
Table 1. Sequences of the primers used in this study

\begin{tabular}{|c|c|c|c|}
\hline Gene & $\begin{array}{c}\text { Accession } \\
\text { number }\end{array}$ & Sequence of the primers & $\begin{array}{l}\text { Product } \\
\text { size (bp) }\end{array}$ \\
\hline StAR & NM031558 & $\begin{array}{l}\text { F 5'- AAA CTG ACT CCA GAG TGC TC } \\
\text { R 5'- TGT CCT TCA CTG TCA GCT TC }\end{array}$ & 528 \\
\hline CYP11A1 & J05156 & $\begin{array}{l}\text { F 5'- CAT CAA GGA GAC ACT GAG AC } \\
\text { R 5'- GCA TCA GGA TGA GGT TGA AC }\end{array}$ & 368 \\
\hline CYP17A1 & NM012753 & $\begin{array}{l}\text { F 5'- CAC CAA CTT TCA ATG ACC GG } \\
\text { R 5'- GCT ACT GCA GAG GTT TGA CT }\end{array}$ & 372 \\
\hline $3 \beta-H S D$ & NM001007719 & $\begin{array}{l}\text { F 5'- CCA CTT GGT CAC ACT GTC AA } \\
\text { R 5'- CTG AGG CAT AAC TAC CTG TG }\end{array}$ & 367 \\
\hline $17 \beta$-HSD & ВC061543 & $\begin{array}{l}\text { F 5'- GGA ACA GAT CCC AGA ATG AC } \\
\text { R 5'- ACA GAC ATG ACC AAC ACT GG }\end{array}$ & 498 \\
\hline CYP19 & NM017085 & $\begin{array}{l}\text { F 5'- CGT CAT GTT GCT TCT CAT CG } \\
\text { R 5'- TCA ATC ACG TCA TCC TCC AG }\end{array}$ & 204 \\
\hline ER- $\alpha$ & NM012689 & $\begin{array}{l}\text { F 5'- GTC GAT TCC GCA TGA TGA AC } \\
\text { R 5'- AAT GTG CTG AAG TGG AGC TG }\end{array}$ & 435 \\
\hline ER- $\beta$ & NM012754 & $\begin{array}{l}\text { F 5'- AAG CTG AAC CAC CCA ATG TG } \\
\text { R 5'- CAA TCA TGT GCA CCA GTT CC }\end{array}$ & 111 \\
\hline LH-R & NM012978 & $\begin{array}{l}\text { F 5'- CCT GAG CAT CTG TAA CAC AG } \\
\text { R 5'- CTG TGC ATC TTC TCC AGG TA }\end{array}$ & 266 \\
\hline GAPDH & NM017008 & $\begin{array}{l}\text { F 5'- CCA TCA CCA TCT TCC AGG AG } \\
\text { R 5'- CCT GTT TCA CCA CCT TCT TG }\end{array}$ & 576 \\
\hline
\end{tabular}

F, forward; R, reverse. The directions of sequences are all $5^{\prime}$ to $3^{\prime}$.

\section{Statistical analysis}

All values are expressed as the means $( \pm$ S.E. $)$. Sex- and depot-dependent differences were analyzed by Student's $t$ test or one-way analysis of variance (ANOVA). $P$ values less than 0.05 were considered significant. The IBM PC programs INSTAT and PRISM 4.01 (GraphPad, USA) were used to calculate and plot the results.

\section{RESULTS}

\section{Histological analyses}

Fig. 1 represents the cross sections of the adipose tissues used in the present study. Adipocytes of WAT from male and female animals were monovacuolar cells contain a large lipid droplet surrounded by a layer of cytoplasm, and their nuclei were flattened and located on the periphery (upper and middle rows). The overall size and shape of female reproductive adipocytes were relatively smaller and more flattened compared to those of abdominal adipocytes. Adipocytes of BAT were polygonal in shape (bottom row). 
Table 2. Specific conditions of PCRs used in this study

\begin{tabular}{|c|c|c|}
\hline Gene & $\begin{array}{c}\text { Temperature \& time } \\
\text { denature / annealing / extension }\end{array}$ & $\begin{array}{l}\text { Number } \\
\text { of cycle }\end{array}$ \\
\hline StAR & $\begin{array}{c}94^{\circ} \mathrm{C}, 40 \mathrm{sec} / 61^{\circ} \mathrm{C}, 1 \mathrm{~min} / \\
72^{\circ} \mathrm{C}, 1 \mathrm{~min}\end{array}$ & 35 \\
\hline CYP11A1 & $\begin{array}{c}94^{\circ} \mathrm{C}, 30 \mathrm{sec} / 65^{\circ} \mathrm{C}, 40 \mathrm{sec} / \\
72^{\circ} \mathrm{C}, 40 \mathrm{sec}\end{array}$ & 35 \\
\hline CYP17A1 & $\begin{array}{c}94^{\circ} \mathrm{C}, 40 \mathrm{sec} / 64^{\circ} \mathrm{C} 1 \mathrm{~min} / \\
72^{\circ} \mathrm{C}, 1 \mathrm{~min}\end{array}$ & 33 \\
\hline $3 \beta$-HSD & $\begin{array}{c}94^{\circ} \mathrm{C}, 30 \mathrm{sec} / 61^{\circ} \mathrm{C}, 40 \mathrm{sec} / \\
72^{\circ} \mathrm{C}, 40 \mathrm{sec}\end{array}$ & 38 \\
\hline $17 \beta$-HSD & $\begin{array}{c}94^{\circ} \mathrm{C}, 30 \mathrm{sec} / 61^{\circ} \mathrm{C}, 40 \mathrm{sec} / \\
72^{\circ} \mathrm{C}, 40 \mathrm{sec}\end{array}$ & 35 \\
\hline CYP19 & $\begin{array}{c}94^{\circ} \mathrm{C}, 30 \mathrm{sec} / 60^{\circ} \mathrm{C}, 40 \mathrm{sec} / \\
72^{\circ} \mathrm{C}, 40 \mathrm{sec}\end{array}$ & 33 \\
\hline ER- $\alpha$ & $\begin{array}{c}94^{\circ} \mathrm{C}, 40 \mathrm{sec} / 68^{\circ} \mathrm{C}, 50 \mathrm{sec} / \\
72^{\circ} \mathrm{C}, 50 \mathrm{sec}\end{array}$ & 38 \\
\hline ER- $\beta$ & $\begin{array}{c}94^{\circ} \mathrm{C}, 30 \mathrm{sec} / 63^{\circ} \mathrm{C}, 40 \mathrm{sec} / \\
72^{\circ} \mathrm{C}, 40 \mathrm{sec}\end{array}$ & 35 \\
\hline LH-R & $\begin{array}{c}94^{\circ} \mathrm{C}, 30 \mathrm{sec} / 61^{\circ} \mathrm{C}, 40 \mathrm{sec} / \\
72^{\circ} \mathrm{C}, 40 \mathrm{sec}\end{array}$ & 32 \\
\hline GAPDH & $\begin{array}{c}94^{\circ} \mathrm{C}, 30 \mathrm{sec} / 61^{\circ} \mathrm{C}, 40 \mathrm{sec} / \\
72^{\circ} \mathrm{C}, 40 \mathrm{sec}\end{array}$ & 24 \\
\hline
\end{tabular}

Compared to WAT adipocytes, these cells have considerable cytoplasm, with much less lipid droplets scattered throughout in the cells. The nuclei were round and not in the periphery of the cells. Female brown adipocytes were amassed showing big 'island' like shape. These cross sections of adipose tissues were in good accordance with previously reported typical characteristics of rat white and brown adipose tissues (Cinti, 2000).

\section{RT-PCRs of steroidogenesis-related factors}

We performed quantitative RT-PCRs for 6 types of genes; Steroidogenic acute regulatory protein (StAR), Cholesterol side-chain cleavage enzyme (P450scc), 3- $\beta$-hydroxysteroid dehydrogenase (3ß-HSD), Cytochrome P450 17A1 (CYP17), 17Beta Hydroxysteroid dehydrogenase (17 $\beta$-HSD) and Aromatase

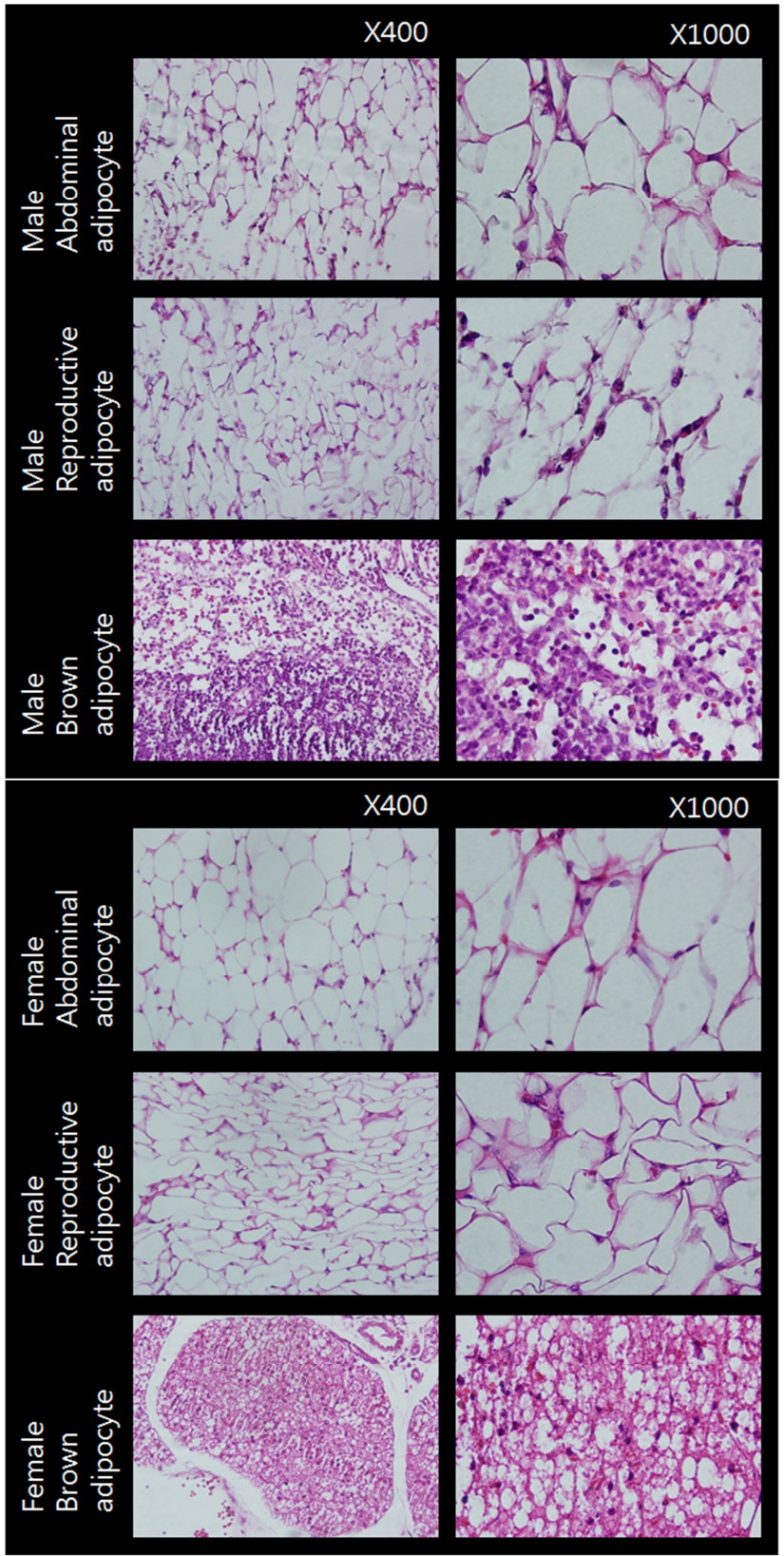

Fig. 1. Histology of the adipose tissues from immature male and female rats. The tissues were collected at PND 30, then were applied to the standard paraffin section and hematoxylin-eosin staining method. Adipocytes of WAT from both sexes were monovacuolar cells contain a large lipid droplet surrounded by a layer of cytoplasm, with flattened nuclei located on the periphery (upper and middle rows). Adipocytes of BAT were polygonal, and have considerable cytoplasm, with much less lipid droplets scattered throughout in the cells (bottom rows). 
(CYP19). All kind of transcripts were successfully amplified, and in overall aspects, the abundances of the transcripts were lower in the BAT of both sexes (Fig. 2, A-F).

There was no significant difference of StAR transcript levels between male and female with same depots. However, the levels of the BAT were significant lower among male depots (MA:MR:MB = 1.00 $\pm 0.16: 0.69 \pm 0.05: 0.37 \pm 0.07, p<0.01$; Fig. 2A). The levels of P450scc transcripts in the BAT were significant lower compared to the other depots in both sexes (MA:MR:MB = 1.00 $\pm 0.10: 0.70 \pm 0.08: 0.52 \pm 0.05$, $p<0.05$; FA:FR:FB $=0.80 \pm 0.09: 0.77 \pm 0.11: 0.41 \pm 0.02, p<0.05$; Fig. 2B). The $3 \beta$-HSD transcripts in female abdominal adipose and reproductive adipose were significantly lower than those of male counterparts (FA:FR:FB $=0.58 \pm 0.11: 0.44 \pm 0.08$ : $0.29 \pm 0.04, p<0.05$; Fig. 2C). In comparison of the levels between depots of same sex, BAT shown significant low abundance (MA:MR:MB = 1.00 $\pm 0.05: 1.10 \pm 0.10: 0.51 \pm 0.12$, $p<0.01$; FA:FR:FB $=0.58 \pm 0.12: 0.44 \pm 0.08: 0.29 \pm 0.05, p<0.01$; Fig. 2C). As with P450scc, the levels of CYP17 transcripts in the BAT were significant lower compared to the other depots in both sexes (MA:MR:MB $=1.00 \pm 0.15: 1.16 \pm 0.11$ : $0.56 \pm 0.04, p<0.05 ; \mathrm{FA}: \mathrm{FR}: \mathrm{FB}=0.77 \pm 0.08: 0.78 \pm 0.10: 0.48 \pm$ 0.07, $p<0.05$, Fig. 2D). The CYP17 transcript levels in female reproductive adipose were significantly lower than that of male counterpart (MR:FR $=1.16 \pm 0.11: 0.78 \pm 0.10$, $p<0.05$; Fig. 2D). The $17 \beta$-HSD transcript levels in female abdominal adipose and reproductive adipose were significantly lower than those of male counterparts (MA:FA = 1.00 $\pm 0.18: 0.48 \pm 0.12, p<0.01 ; \mathrm{MR}: \mathrm{FR}=1.05 \pm 0.22: 0.22 \pm 0.03$, $p<0.01$; Fig. $2 \mathrm{E}$ ). The levels of $17 \beta$-HSD transcripts in the BAT were significant lower compared to the other depots in both sexes (MA:MR:MB = 1.00 $\pm 0.16: 1.05 \pm 0.22: 0.28 \pm 0.08$, $p<0.01$; FA:FR:FB $=0.48 \pm 0.02: 0.22 \pm 0.03: 0.16 \pm 0.02, p<0.01$; Fig. 2E). The CYP19 transcripts level in female abdominal adipose were significantly lower than those of male counterparts (MA:FA $=1.00 \pm 0.16: 0.51 \pm 0.05, p<0.05$; Fig. $2 \mathrm{~F}$ ). In male, the levels of CYP19 transcripts of reproductive
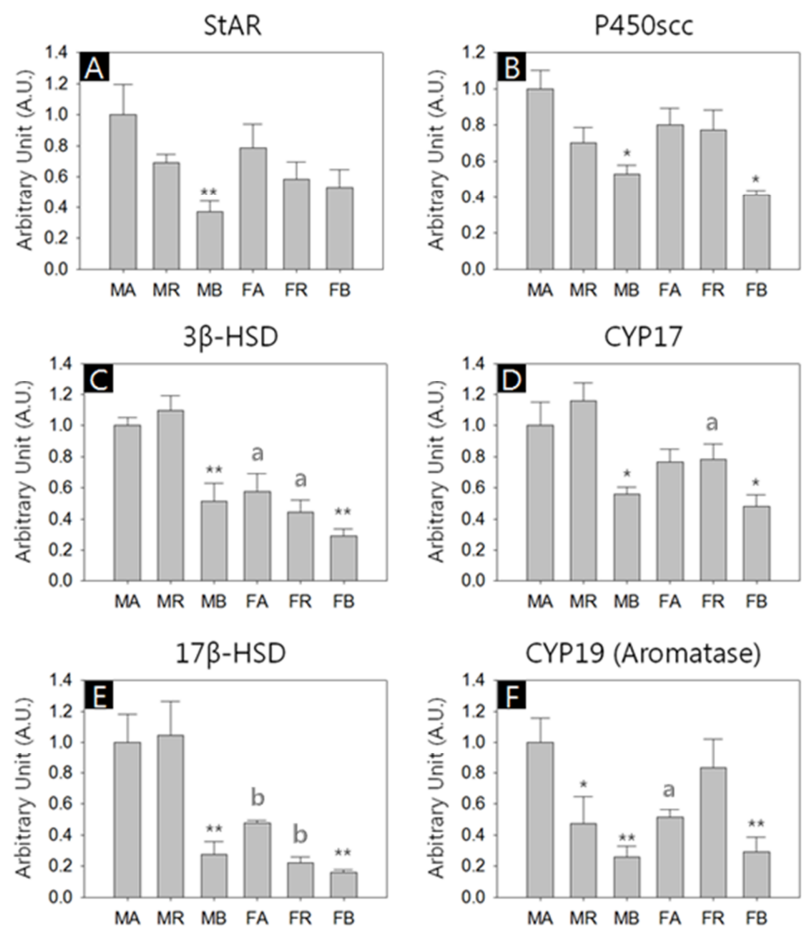

Fig. 2. Measurements of the transcript levels of the six steroidogenesis-related genes in the adipose tissues from immature male and female rats. On PND 30, the adipose tissues were collected and applied to RNA extraction. RT-PCRs were performed using the specific primers and conditions described in Tables 1 and 2. Values are expressed as mean \pm S.E. ( $n=6-8$ per group). AU, arbitrary unit; MA, Male abdominal adipose tissue; MR, Male reproductive adipose tissue; MB, Male brown adipose tissue; FA, Female abdominal adipose tissue; FR, Female reproductive adipose tissue; FB, Female brown adipose tissue. *, Significant difference between the depots in the same sex, $p<0.05$. $^{* *}$, Significant difference between the depots in the same sex, $p<0.01$. a, Significant difference between the sexes (same depot), $p<0.05$. b, Significant difference between the sexes (same depot), $p<0.01$.

adipose and BAT were significant lower compared to the abdominal adipose (MA:MR:MB = 1.00 $\pm 0.16: 047 \pm 0.18$ : $0.26 \pm 0.07, p<0.05, p<0.01$, respectively; Fig. $2 \mathrm{~F}$ ). In female, the levels of CYP19 transcripts of BAT were significant lower compared to those of other depots (FA:FR:FB = 
0.51 $\pm 0.05: 0.83 \pm 0.19: 0.29 \pm 0.10, p<0.01$; Fig. $2 \mathrm{~F})$.

\section{RT-PCRs of hormone receptors}

In another sets of RT-PCR, we measured the transcriptional activities of estrogen receptor-alpha (ER- $\alpha$ ), estrogen receptor-beta (ER- $\beta$ ) and luteinizing hormone receptor (LHR). All kinds of transcripts were successfully amplified. Similar to steroidogenic factors, the abundances of the receptor transcripts were generally lower in the BAT of both sexes. ER- $\beta$ transcripts were more abundant in male WAT depots than their female counterparts (Fig. 3, A-C). The levels of ER- $\alpha$ transcripts in the BAT were significant lower compared to the other depots in both sexes (MA:MR:MB = 1.00 $\pm 0.09: 1.02 \pm 0.11: 0.64 \pm 0.10, p<0.05 ; \mathrm{FA}: \mathrm{FR}: \mathrm{FB}=1.05 \pm$
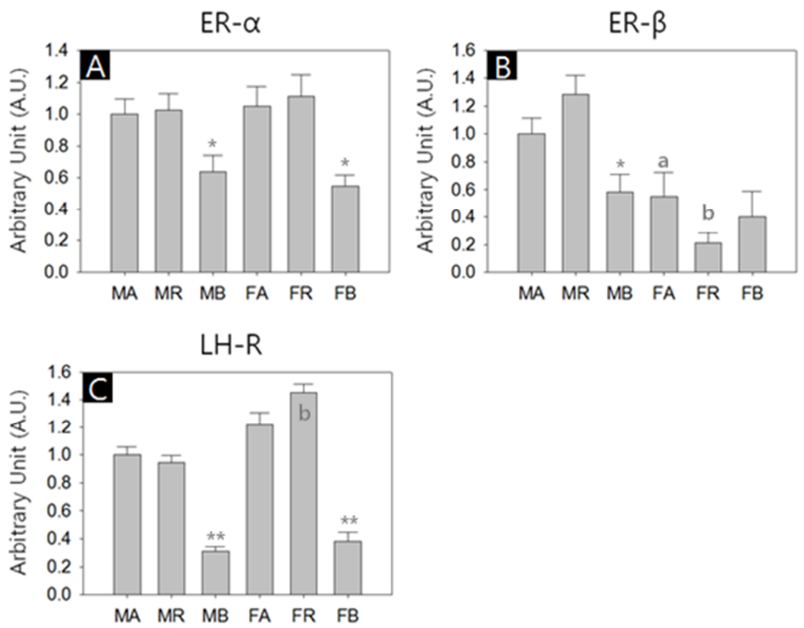

Fig. 3. Measurements of the transcript levels of the hormone receptor genes in the adipose tissues from immature male and female rats. RT-PCRs were performed using the specific primers and conditions described in Tables 1 and 2. Values are expressed as mean \pm S.E. ( $n=6-8$ per group). *, Significant difference between the depots in the same sex, $p<0.05$. **, Significant difference between the depots in the same sex, $p<0.01$. a, Significant difference between the sexes (same depot), $p<0.05$. $b$, Significant difference between the sexes (same depot), $p<0.01$.
0.13:1.11 $\pm 0.13: 0.55 \pm 0.07, p<0.05$; Fig. $3 \mathrm{~A})$. The ER- $\beta$ transcript levels in female abdominal adipose and reproductive adipose were significantly lower than those of male counterparts (MA:FA $=1.00 \pm 0.12: 0.55 \pm 0.17, p<0.05$ MR:FR = 1.29 $\pm 0.13: 0.21 \pm 0.07, p<0.01$, respectively; Fig. $3 B)$. In male, the levels of ER- $\beta$ transcripts of BAT were significant lower compared to those of other depots (MA: MR:MB = 1.00 $\pm 0.12: 1.29 \pm 0.13: 0.59 \pm 0.12, p<0.05 ;$ Fig. 3B). The levels of LHR transcripts in female reproductive adipose were significantly higher than those of male counterpart (MR:FR $=0.95 \pm 0.05: 1.46 \pm 0.06, p<0.01$; Fig. 3C) In comparison of the LHR transcript levels between depots of same sex, BAT shown significant low abundance (MA: MR:MB $=1.00 \pm 0.05: 0.95 \pm 0.05: 0.31 \pm 0.03, p<0.01 ;$ FA:FR:FB $=1.22 \pm 0.09: 1.46 \pm 0.06: 0.38 \pm 0.07, p<0.01$; Fig. $3 \mathrm{C}$ ).

\section{DISCUSSION}

The obesity epidemic is one of most serious global issue and shows explosive growth without any sign of diminishing, while the cause and solutions remain unclear. Naturally, a large amount of research had been conducted to clarify the physiology of adipose tissues. For example, the influence of sex on adipose tissue distribution and function, and its implication in metabolic syndrome has been known for a long time (Mayes \& Watson, 2004; Fuente-Martín et al., 2013). The distribution of fat in gynoid and android shapes of adult humans is a consequence of the close interrelationship of adipose tissue with androgens and estrogens (Kotani et al., 1994). On human cases, two studies revealed that there are clear differences between male female even before the onset of puberty. Sex differences in body fat distribution are present in prepubertal children but that the specific characteristics for Asians differ from African-Americans and Caucasians (He et al., 2002). The other study also demonstrated that sexual dimorphism in fat patterning is apparent prepubertally, and the magnitude of the sex difference is amplified with 
maturation, particularly from late puberty to early adulthood (Taylor et al., 2010). In the present study we used immature rats (PND 30), and found the sex-specific expressions of steroid synthesizing genes, generally higher in male animals.

Adipose tissues had been thought for a long time as a simple storage organ for triacylglycerol. However, view of adipose tissue dramatically changed to significant endocrine organ by the discovery of leptin in the mid-1990s (Pelleymounter et al., 1995). Indeed, adipose tissues synthesize and release not only leptin but numerous protein hormones, growth factors and cytokines, collectively known as 'adipokines', and steroid hormones ( $\mathrm{Li}$ et al., 2015). Estrogens in men and in postmenopausal women are principally produced by adipose tissue from circulating steroid precursors (Grodin et al., 1973). Similar phenomenon, aromatization of androgens to estrogen, was found in castrated obese rats (Drago et al., 1982). Besides the conversion of various steroid precursors from circulation, recent studies revealed that the adipose tissues are equipped with steroidogenic machinery for $d e$ novo synthesis from cholesterol, initiated by StAR and CYP11A1 (Atzmon et al., 2002; MacKenzie et al., 2008b; Li et al., 2015). Our finding that adipose tissues express the StAR and steroidogenic enzymes in the pathway from cholesterol to active steroid hormones supports the de novo steroid synthesis in adipose tissues. Within hippocampus and cerebellum from normal and Alzheimer's disease patients, on the other hand, ten steroid-associated genes were transcribed except for CYP11B1 (11beta-hydroxylase), CYP11B2 (aldosterone synthase) and CYP17 (17alpha-hydroxylase) (MacKenzie et al., 2008a). Without these key mRNAs, human hippocampus and cerebellum rule out the de novo synthesis of aldosterone, cortisol or the sex steroids.

Two estrogen receptor isoforms, ER- $\alpha$ and ER- $\beta$, are present in mitochondria of WATs, suggesting important influences on adipocyte metabolism and proliferation (Pedersen et al., 2001; Dos Santos et al., 2010). In the present study, we found that the expressions of ER- $\alpha$ and ER- $\beta$ in all adipose tissues of both sexes. ER- $\alpha$ expressions in BATs of both sexes were significantly less than those in the WATs. ER- $\beta$ expressions in female abdominal and reproductive fats were significantly less than those of male counterparts. We speculate that the ER- $\beta$ expression pattern could be a reflection of prepubertal sex differences. There is evidence that both ER- $\alpha$ and ER- $\beta$ were expressed in human fetal brown adipose tissue(fBAT), with ER $\alpha$ being dominant (Velickovic et al., 2014). The authors demonstrated that ER- $\beta$ was present only in mature brown adipocytes while ER- $\alpha$ was in mature adipocytes and preadipocytes, and suggested a dominant role for ER- $\alpha$ in its development and, fBAT mitochondria could be targeted by estrogens (Velickovic et al., 2014). Finally, there is a report on the HCG/LH receptor expression in human preadipocytes, and our data about LHR expression in rat adipose tissues confirm the finding (Dos Santos et al., 2007).

Special attention should be paid to transgender population when they undergo cross-sex hormone therapy. In transgender women, estrogen therapy, with or without antiandrogen therapy, was associated with lower blood pressure, while transgender men who take testosterone therapy were associated with increased body mass index (Deutsch et al., 2015). We speculate that long-term exogenous steroid supplements can induce a broad range of steroid-associated changes, including physiological and biochemical status of adipose tissues, and probably disturb body energy homeostasis and possibly cause unhealthy condition.

In conclusion, our study demonstrated that the expressions of steroidogenesis-related genes (StAR, enzymes and hormone receptors) were occurred in the immature male and female rat adipose tissues. The expression patterns were depotspecific and sex-specific, and particularly, overall expression intensities in brown adipose of both sexes shown lower than other depots. Taken together, our study suggested that the adipose tissues are not only targets but de novo synthesizing sites of sex steroid(s), though the synthesizing 
activities could be much less than in gonads. Further researches in this field will be helpful for understanding the adipose physiology and for medical application such as sex-specific steroid supplement therapies for older populations.

\section{ACKNOWLEDGEMENT}

This research was supported by a 2014 Research Grant from Sangmyung University.

\section{REFERENCES}

Atzmon G, Yang XM, Muzumdar R, Ma XH, Gabriely I, Barzilai N (2002) Differential gene expression between visceral and subcutaneous fat depots. Horm Metab Res $34: 622-628$.

Bjorntorp P (1996) The regulation of adipose tissue distribution in humans. Int J Obes 20: 291-302.

Cinti S (2000) Anatomy of the adipose organ. Eat Weight Disord 5:132-142.

Coelho M, Oliveira T, Fernandes R (2013) Biochemistry of adipose tissue: an endocrine organ. Arch Med Sci 9:191-200.

Deutsch MB, Bhakri V, Kubicek K (2015) Effects of cross-sex hormone treatment on transgender women and men. Obstet Gynecol 125:605-610.

Dos Santos E, Dieudonné MN, Leneveu MC, Pecquery R, Serazin V, Giudicelli Y (2007) In vitro effects of chorionic gonadotropin hormone on human adipose development. J Endocrinol 194:313-325.

Dos Santos E, Dieudonné MN, Leneveu MC, Sérazin V, Rincheval V, Mignotte B, Chouillard E, De Mazancourt P, Giudicelli Y, Pecquery R (2010) Effects of 17betaestradiol on preadipocyte proliferation in human adipose tissue: Involvement of IGF1-R signaling. Horm Metab Res 42:514-520.

Drago F, Lo Presti L, Nardo F, Panella I, Matera M,
Scapagnini U (1982) Aromatization of testosterone by adipose tissue and sexual behavior of castrated male rats. Biol Reprod 27:765-770.

Fuente-Martín E, Argente-Arizón P, Ros P, Argente J, Chowen JA (2013) Sex differences in adipose tissue: It is not only a question of quantity and distribution. Adipocyte 2:128-134.

Grodin JM, Siiteri PK, MacDonald PC (1973) Source of estrogen production in postmenopausal women. J Clin Endocrinol Metab 36:207-214.

He Q, Horlick M, Thornton J, Wang J, Pierson RN Jr, Heshka S, Gallagher D (2002) Sex and race differences in fat distribution among Asian, African-American, and Caucasian prepubertal children. J Clin Endocrinol Metab 87:2164-2170.

Kotani K, Tokunaga K, Fujioka S, Kobatake T, Keno Y, Yoshida S, Shimomura I, Tarui S, Matsuzawa Y (1994) Sexual dimorphism of age-related-changes in wholebody fat distribution in the obese. Int J Obesity 18:207212.

Li J, Daly E, Campioli E, Wabitsch M, Papadopoulos V (2014) De novo synthesis of steroids and oxysterols in adipocytes. J Biol Chem 289:747-764.

Li J, Papadopoulos V, Vihma V (2015) Steroid biosynthesis in adipose tissue. Steroids 103:89-104.

MacKenzie SM, Dewar D, Stewart W, Fraser R, Connell JM, Davies E (2008a) The transcription of steroidogenic genes in the human cerebellum and hippocampus: A comparative survey of normal and Alzheimer's tissue. J Endocrinol 196:123-130.

MacKenzie SM, Huda SS, Sattar N, Fraser R, Connell JM, Davies E (2008b) Depot-specific steroidogenic gene transcription in human adipose tissue. Clin Endocrinol (Oxf) 69:848-854.

Mayes JS, Watson GH (2004) Direct effects of sex steroid hormones on adipose tissues and obesity. Obes Rev 5:197-216. 
Pedersen SB1, Bruun JM, Hube F, Kristensen K, Hauner H, Richelsen B (2001). Demonstration of estrogen receptor subtypes alpha and beta in human adipose tissue: Influences of adipose cell differentiation and fat depot localization. Mol Cell Endocrinol 182:27-37.

Pelleymounter MA, Cullen MJ, Baker MB, Hecht R, Winters D, Boone T, Collins F (1995) Effects of the obese gene product on body weight regulation in ob/ob mice. Science 269:540-543.

Taylor RW, Grant AM, Williams SM, Goulding A (2010) Sex differences in regional body fat distribution from pre- to postpuberty. Obesity 18:1410-1416.
Velickovic K, Cvoro A, Srdic B, Stokic E, Markelic M, Golic I, Otasevic V, Stancic A, Jankovic A, Vucetic M, Buzadzic B, Korac B, Korac A (2014) Expression and subcellular localization of estrogen receptors $\alpha$ and $\beta$ in human fetal brown adipose tissue. J Clin Endocrinol Metab 99:151-159.

Yoo DK, Lee S-H (2016) Effect of lipopolysaccharide (LPS) exposure on the reproductive organs of immature female rats. Dev Reprod 20:91-99.

Zhao H, Tian Z, Hao J, Chen B (2005) Extragonadal aromatization increases with time after ovariectomy in rats. Reprod Biol Endocrinol 3:6. 